\title{
Analysis of the murine sperm surface with monoclonal antibodies
}

\author{
D. N. Crichton and B. B. Cohen \\ M.R.C. Clinical and Population Cytogenetics Unit, Western General Hospital, Crewe Road, \\ Edinburgh EH4 $2 X U$, U.K.
}

\begin{abstract}
Summary. Hybridomas secreting monoclonal antibodies reactive with murine spermatozoa were produced by fusion of myeloma cells with spleen cells from C57BL/6J mice immunized with spermatozoa from mice of the same strain. All antisperm antibodies were of the $\mu(\mathrm{mu})$ immunoglobulin heavy chain class; only one (MS-1) bound S. aureus protein A. Antibody MS-1 recognized an antigen present on the sperm acrosomal cap, on the surface of cells from liver and kidney and from some cultured cell lines. The subunit molecular weight $(69000)$ of the polypeptide reactive with MS-1 was determined by SDS-PAGE analysis of sperm membrane proteins followed by their electrophoretic transfer to nitrocellulose.
\end{abstract}

\section{Introduction}

Knowledge of the molecular structure of the mammalian sperm surface is important for an understanding of the events of fertilization, the involvement of gametic antigens in infertility and for the evaluation of an immunological approach to contraception (Metz, 1972). The spermatozoa of mammals gain the ability to fertilize during passage through the epididymis (Bedford, Cooper \& Calvin, 1972; Feuchter, Vernon \& Eddy, 1981). Amongst the changes concomitant with the formation and maturation of the male gamete is the appearance of several differentiation antigens (Toullet \& Voisin, 1974; Millette \& Bellvé, 1977). Several studies have also documented the presence of histocompatibility antigens on spermatozoa (Fellous \& Dausset, 1970; Goldberg, Aoki, Boyse \& Bennett, 1970; Goldberg, Boyse, Bennett, Scheid \& Carswell, 1971; Vojtiskova \& Pokorna, 1972; Erickson, 1972) and it has been suggested that these may be important in cell-cell recognition at the gametic level (Festenstein, Halim \& Arnaiz-Villena, 1979). The haploid expression of HLA antigens on human spermatozoa (Fellous \& Dausset, 1970) and the limited expression of H-Y (male-specific) antigen on mouse spermatozoa (Bennett \& Boyse, 1973) have promised exciting opportunities for manipulation of the sex ratio. A major disadvantage of conventional antisera employed in the serological investigation of sperm surface molecules is that they contain antibodies against multiple determinants, frequently rendering the interpretation of results ambiguous. The immortalization of single antibody-secreting cells by somatic cell hybridization (Köhler \& Milstein, 1975) permits production of highly specific reagents (monoclonal antibodies) that recognize individual determinants. The aim of the present study was to investigate the mouse sperm surface using monoclonal antibodies produced after autosomal sygeneic immunization.

\section{Materials and Methods}

Immunization and cell fusion. Two 8-week-old female C57BL/6J (B6) mice were immunized by intraperitoneal (i.p.) injection of $5 \times 10^{6}$ spermatozoa in Dulbecco's phosphate-buffered saline $\mathrm{pH}$ $7 \cdot 4$ (PBS) from B6 males. They were boosted after 11 days with $5 \times 10^{6}$ spermatozoa i.p. and after 
156 and 163 days with $10^{7}$ spermatozoa intravenously. Spleens were removed 3 days later and used as a source of immune cells for fusion to the BALB/c myeloma line P3-NS/1-Ag-1 (obtained from Dr P. N. Goodfellow, ICRF, Lincoln's Inn Fields, London, U.K.) at a spleen cell to myeloma cell ratio of 5 to 1 . Fusion products were suspended in HAT selection medium (RPMI 1640 containing $20 \%$ fetal calf serum, antibiotics, $10^{-4} \mathrm{M}$-hypoxanthine, $10^{-6} \mathrm{M}$-aminopterin, $1.6 \times 10^{-5} \mathrm{M}$ thymidine, $1 \mathrm{~mm}$-oxaloacetic acid, $0.45 \mathrm{~mm}$-sodium pyruvate, 0.2 units porcine insulin $/ \mathrm{ml}$ and 12.5 mM-3-( $N$-morpholine)propane sulphonic acid (MOPS); modified from Kennet, Denis, Tung \& Klinman, 1978). The medium also contained $10^{6}$ male BALB $/ \mathrm{c}$ mouse macrophages $/ \mathrm{ml}$ as feeder cells and was dispensed into twelve 96-well microtitre plates. Cultures were fed by replacing the medium in the wells every 3 or 4 days. Cloning was performed twice by limiting dilution.

Serological techniques. Supernatants from cultures showing growth were tested in an indirect cellular radioimmunoassay (Mason \& Williams, 1980) against mouse spermatozoa. Duplicate aliquants $(50 \mu \mathrm{l})$ of culture supernatant were incubated at $4{ }^{\circ} \mathrm{C}$ for $60 \mathrm{~min}$ or overnight with $2 \times 10^{5}$ glutaraldehyde-fixed (Williams, 1973) target cells in $50 \mu \mathrm{l} \mathrm{PBS}$ containing $2 \%$ bovine serum albumin (PBS-BSA). The target cells were washed three times and resuspended in $50 \mu \mathrm{l}$ columnpurified rabbit $\mathrm{F}\left(\mathrm{ab}^{\prime}\right)_{2}$ antimouse immunoglobulin (a gift from $\operatorname{Dr} \mathrm{A}$. F. Williams, MRC Cellular Immunology Group, Oxford, U.K.) labelled with iodine-125 by the method of Jensenius \& Williams (1974). The specific activity of the labelled antibody was approximately $60 \mu \mathrm{Ci} / \mu \mathrm{g} ; 2.5 \times$ $10^{5}$ c.p.m. were added to each well. After a further incubation at $4{ }^{\circ} \mathrm{C}$ for $60 \mathrm{~min}$ the cells were washed 3 times and transferred to clean tubes for counting. Background binding was assessed in wells containing target cells suspended in PBS-BSA. Binding three times above background was taken as a positive result. Selected supernatants were subsequently tested more extensively against panels of glutaraldehyde-fixed target cells (Text-fig. 1).

Protein $A$ binding. Antisperm antibodies were examined for protein A binding in parallel cellular radioimmunoassays with mouse spermatozoa by comparing ${ }^{125}$ I-labelled rabbit $F\left(\mathrm{ab}^{\prime}\right)_{2}$ antimouse immunoglobulin and ${ }^{125} \mathrm{I}$-labelled protein A (Amersham International, Amersham, U.K.) as detecting reagents. Biosynthetically labelled monoclonal antibodies were then examined for direct binding to Staphylococcus aureus. Hybridoma cells $\left(2 \times 10^{6}\right)$ were washed 3 times in PBS and incubated overnight $(16 \mathrm{~h})$ in $1 \mathrm{ml} \mathrm{Ham}$ 's F10 medium, lacking lysine but supplemented with $10 \%$ dialysed FCS, $12.5 \mathrm{~mm}$-MOPS and $12.5 \mu \mathrm{Ci} \mathrm{L}-\left[{ }^{14} \mathrm{C}\right] l y s i n e$ (sp. act. $339 \mathrm{mCi} / \mathrm{mmol}$; Amersham International) $/ \mathrm{ml}$. Heat- and formalin-fixed $S$. aureus (Cowan I strain, NCTC-8530, CAMR Microbial Products, Porton Down, Wilts, U.K.) were washed three times with PBS containing $0.5 \%$ Nonidet P40 (NP40; Shell, Manchester, U.K.) and $25 \mu \mathrm{l}$ of a $10 \%$ (v/v) bacterial suspension incubated with $10^{5}$ trichloroacetic acid-precipitable c.p.m. ${ }^{14} \mathrm{C}$-labelled monoclonal antibody for $30 \mathrm{~min}$ at room temperature $\left(21^{\circ} \mathrm{C}\right)$. After washing the bacteria 3 times with PBS-NP40, bound radioactivity was eluted by boiling the cells for $2 \mathrm{~min}$ in $25 \mu 10.0625 \mathrm{M}$-Tris- $\mathrm{HCl}(\mathrm{pH} 6.8$ ), $10 \%$ glycerol, $5 \%$ 2-mercaptoethanol, $2 \%$ sodium dodecyl sulphate (SDS) and $0.001 \%$ bromophenol blue, and electrophoresed on $10 \%$ polyacrylamide gels as described by Laemmli (1970). The gels were impregnated with autoradiography enhancer (En ${ }^{3}$ Hance: New England Nuclear, Southampton, U.K.), dried and exposed to X-ray film (Kodak Xomat RP: Kodak, Glasgow, U.K.) at $-70^{\circ} \mathrm{C}$. Apparent molecular weights were calculated according to the method of Weber \& Osborn (1969).

Determination of immunoglobulin class. The class of the secreted monoclonal antibody was determined by radial immunodiffusion using heavy chain (Miles Laboratories, Slough, U.K.) and light chain (Nordic Immunological Laboratories, Maidenhead, U.K.) class specific antisera.

Immunofluorescence and FACS analysis. Fresh B6 spermatozoa washed 3 times in PBS were resuspended in an excess of culture supernatant and incubated at $4^{\circ} \mathrm{C}$ for $15 \mathrm{~min}$. The cells were washed 3 times and resuspended in fluorescein isothiocyanate-conjugated rabbit antimouse immunoglobulins (Nordic Immunological Laboratories) diluted 1 in 5 in PBS for a further 15 min at $4^{\circ} \mathrm{C}$. After washing 3 times, the cells were examined and photographed using a combination of phase-contrast and u.v. epi-illumination in a Leitz Ortholux II microscope. Additional samples were examined and sorted in a fluorescence-activated cell sorter (FACS) (Green, Molloy \& Steel, 1980). 
Biochemical analysis. Spermatozoa from the vasa deferentia and epididymides of $20 \mathrm{BALB} / \mathrm{C}$ mice were washed 3 times in PBS and membrane proteins were extracted by resuspending the spermatozoa in $0.5 \mathrm{ml}$ extraction buffer $(0.5 \% \mathrm{w} / \mathrm{v}$ NP40 in $10 \mathrm{~mm}-\mathrm{Tris}-\mathrm{HCl} \mathrm{pH} 7 \cdot 2,0.15 \mathrm{M}-\mathrm{NaCl}$, $0.02 \% \mathrm{w} / \mathrm{v} \mathrm{NaN}, 0.1 \mathrm{~mm}$-phenylmethylsulphonyl fluoride $1 \mathrm{mM}_{3}-\mathrm{MgCl}_{2}, 500$ kallikrein inactivator units $/ \mathrm{ml}$ aprotinin (Trasylol: Bayer, Haywards Heath, Sussex, U.K.) for $20 \mathrm{~min}$ on ice. Insoluble material was removed by centrifugation for $15 \mathrm{~min}$ at $4{ }^{\circ} \mathrm{C}$ in an Eppendorf model 5414 Microfuge. Aliquants of the supernatant were electrophoresed in $5-20 \%$ linear concentration gradient SDSpolyacrylamide gels (Laemmli, 1970) under reducing and non-reducing conditions. The separated proteins were transferred electrophoretically from the gel onto a sheet of nitrocellulose (Schleicher and Schuell BA85: Anderman \& Co., Surrey, U.K.) according to the method of Burnette (1981).

Immediately after transfer the nitrocellulose sheet was immersed in a solution containing 10 mM-Tris- $\mathrm{HCl} \mathrm{pH} \mathrm{7.4,} 0.15 \mathrm{M}-\mathrm{NaCl}$ and $2.5 \% \mathrm{w} / \mathrm{v}$ bovine serum albumin (Tris-saline-BSA) for 30 min at room temperature and then incubated in hybridoma culture supernatant for $90 \mathrm{~min}$. The sheet was washed for $10 \mathrm{~min}$ in Tris-saline, two changes of Tris-saline containing $0.05 \% \mathrm{w} / \mathrm{v}$ $\mathrm{NP} 40$, each for $20 \mathrm{~min}$, and finally for $10 \mathrm{~min}$ in Tris-saline alone. The nitrocellulose was then

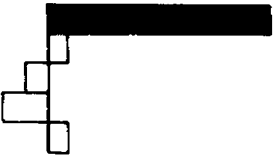

Mouse spermatozoa

Rabbit spermatozoa

Echinus spermatozoa

Human spermatozoa

W50 murine fibrosarcoma

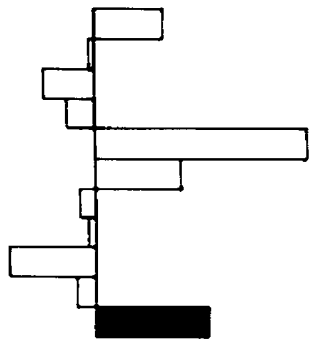

Liver

Brain

B6 rbc

Sheep rbc

Testis

Kidney

Epidermal cells

Spleen

Thymus

Peritoneal macrophages

Spermatozoa

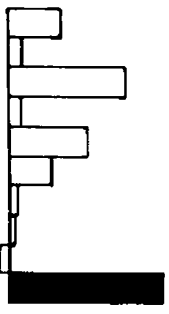

W52 murine fibrosarcoma W68 murine fibrosarcoma W88 murine fibrosarcoma $\mathrm{X} 63 \mathrm{NS}_{1}$ myeloma

A9 fibroblast (HGPRT-)

B82 fibroblast (TK-)

HX39 human teratocarcinoma $\mathrm{T} 3 \mathrm{~B}$, human teratocarcinoma IMR-32 human neuroblastoma Spermatozoa

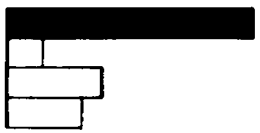

Spermatozoa

B6 lung fibroblasts

PC13 murine teratocarcinoma

PSA4 murine teratocarcinoma

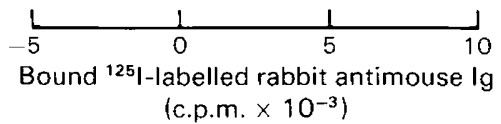

Text-fig. 1. Binding of antibody MS-1 to spermatozoa, adult mouse tissues and cultured cell lines. 
incubated for $30 \mathrm{~min}$ with Tris-saline-BSA containing $10^{5}$ c.p.m. ${ }^{125} \mathrm{I}$-rabbit $\mathrm{F}\left(\mathrm{ab}^{\prime}\right)_{2}$ antimouse immunoglobulin $/ \mathrm{ml}$, washed as described above, dried at $37^{\circ} \mathrm{C}$ and exposed at $-70^{\circ} \mathrm{C}$ to Kodak XOmat RP X-ray film.

\section{Results}

Of the 1056 cultures (one plate was lost through contamination), 501 (47\%) showed growth and 24 $(2 \%)$ produced antibody recognizing the immunogen by radioimmunoassay. The specificity of these antibodies was further studied on a diverse panel of spermatozoa, adult mouse tissues and cultured cell lines; none was able to discriminate between male and female cells. The results for the culture (MS-1) showing the most restricted tissue distribution are shown in Text-fig. 1. The monocional antibody MS-1 appeared to react with an antigen present on mouse spermatozoa, liver and kidney which is absent from other somatic tissues of the mouse. The antigen was also present to a variable degree on some of the cultured cell lines examined.

All 24 of the antisperm antibodies were of the mu $(\mu)$ and kappa $(\kappa)$ heavy and light chain classes of immunoglobulin by their reactivity in radial immunodiffusion with antisera specific for those classes and by their failure to react with antisera directed against other classes and subclasses of mouse immunoglobulins. Of 14 of these mouse IgM monoclonal immunoglobulins examined,

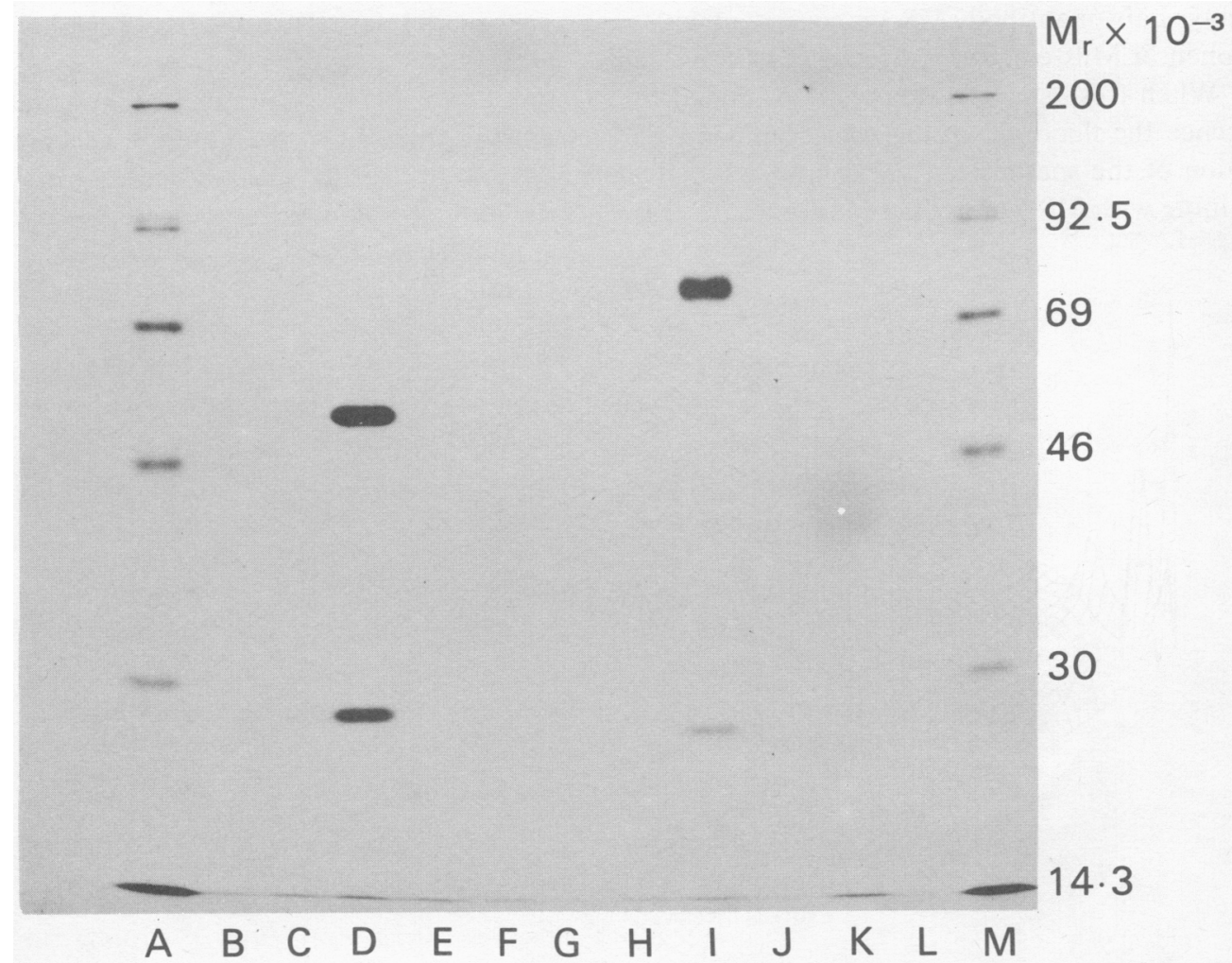

Text-fig. 2. SDS-PAGE analysis of biosynthetically labelled and reduced monoclonal antibodies bound to and eluted from $S$. aureus. Of 4 antisperm antibodies (lanes H-K) only MS-I (lane I) was reactive. Elution of an IgG antibody (lane D) from earlier work is shown for comparison. Lanes $A$ and $\mathbf{M}$ contained ${ }^{14} \mathrm{C}$-methylated protein standards: myosin $\left(\mathbf{M}_{\mathbf{r}}\right.$ $200000)$, phosphorylase $b\left(M_{r} 92500\right)$, bovine serum albumin $\left(M_{r} 69000\right)$, ovalbumin $\left(M_{r}\right.$ $46000)$, carbonic anhydrase $\left(M_{r} 30000\right)$, and ribonuclease $A\left(M_{r} 14300\right)$. 


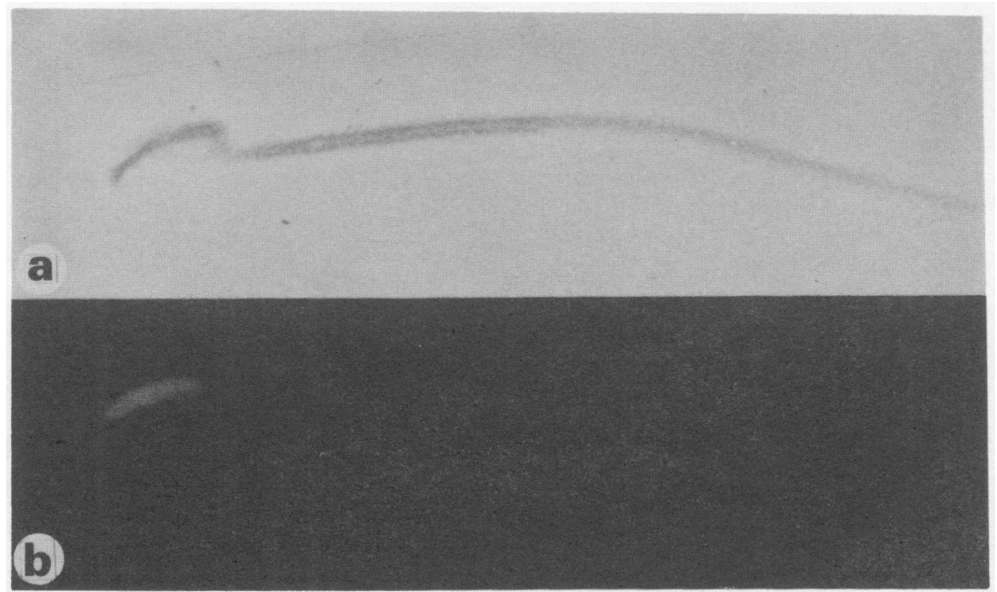

Text-fig. 3. Acrosomal staining of spermatozoon with antibody MS-1: (a) phase contrast; (b) immunofluorescence.

only MS-1 bound ${ }^{125}$ I-labelled protein A, as shown by radioimmunoassay. This was subsequently confirmed by SDS-PAGE analysis of biosynthetically labelled monoclonal antibodies bound directly to and eluted from $S$. aureus (Text-fig. 2). The apparent molecular weight (78 000) of the heavy chain of antibody MS-1 is consistent with values previously reported for IgM macroglobulins (Cohen \& Milstein, 1967; Metzger, 1970).

When fresh spermatozoa were examined for reactivity with MS-1 by indirect immunofluorescence the fluorescent label was confined to a crescent-shaped area of the anterior acrosomal region of the sperm head (Text-fig. 3); $42 \%$ (range 18-59\%) of spermatozoa showed acrosomal staining with MS-1 under the conditions described. None of the contaminating cells were stained.

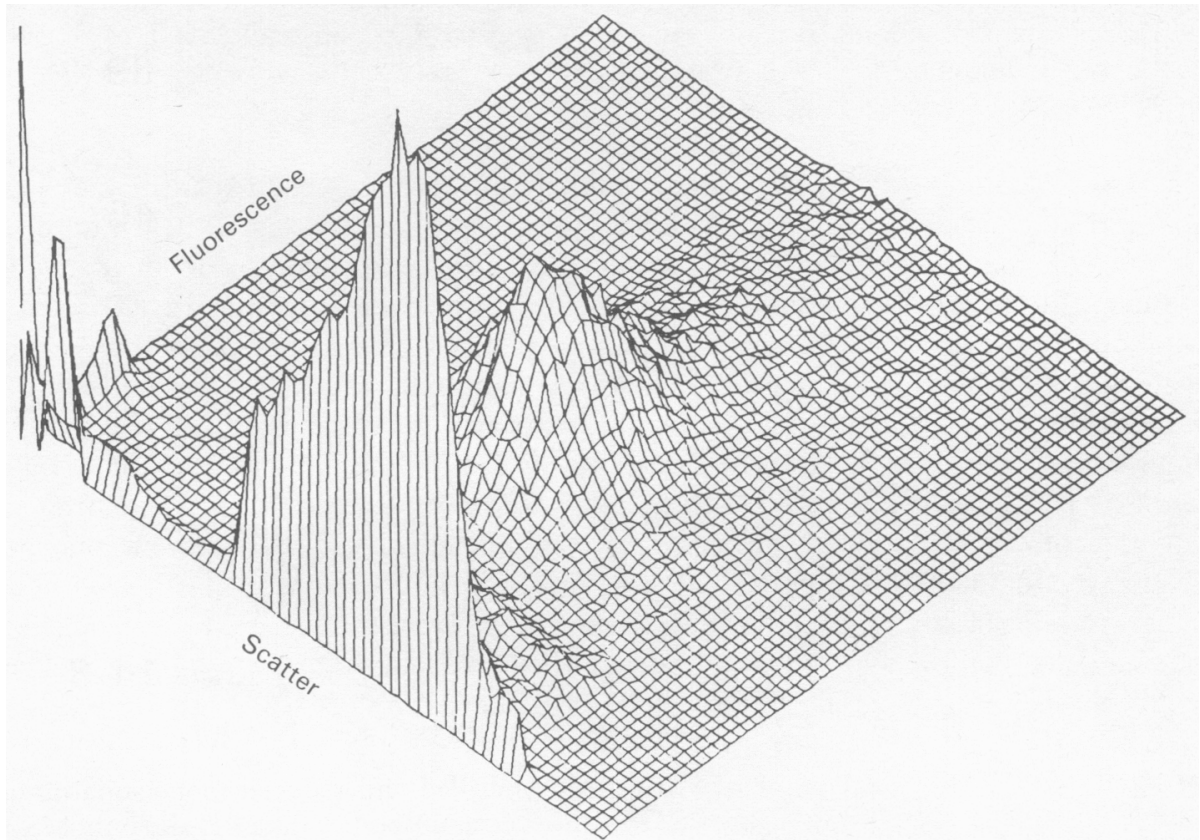

Text-fig. 4. Isometric plot of fluorescence intensity against scatter (representing cell size) after FACS analysis of unfractionated spermatozoa stained with antibody MS-1 and FITCconjugated rabbit antimouse immunoglobulins. 


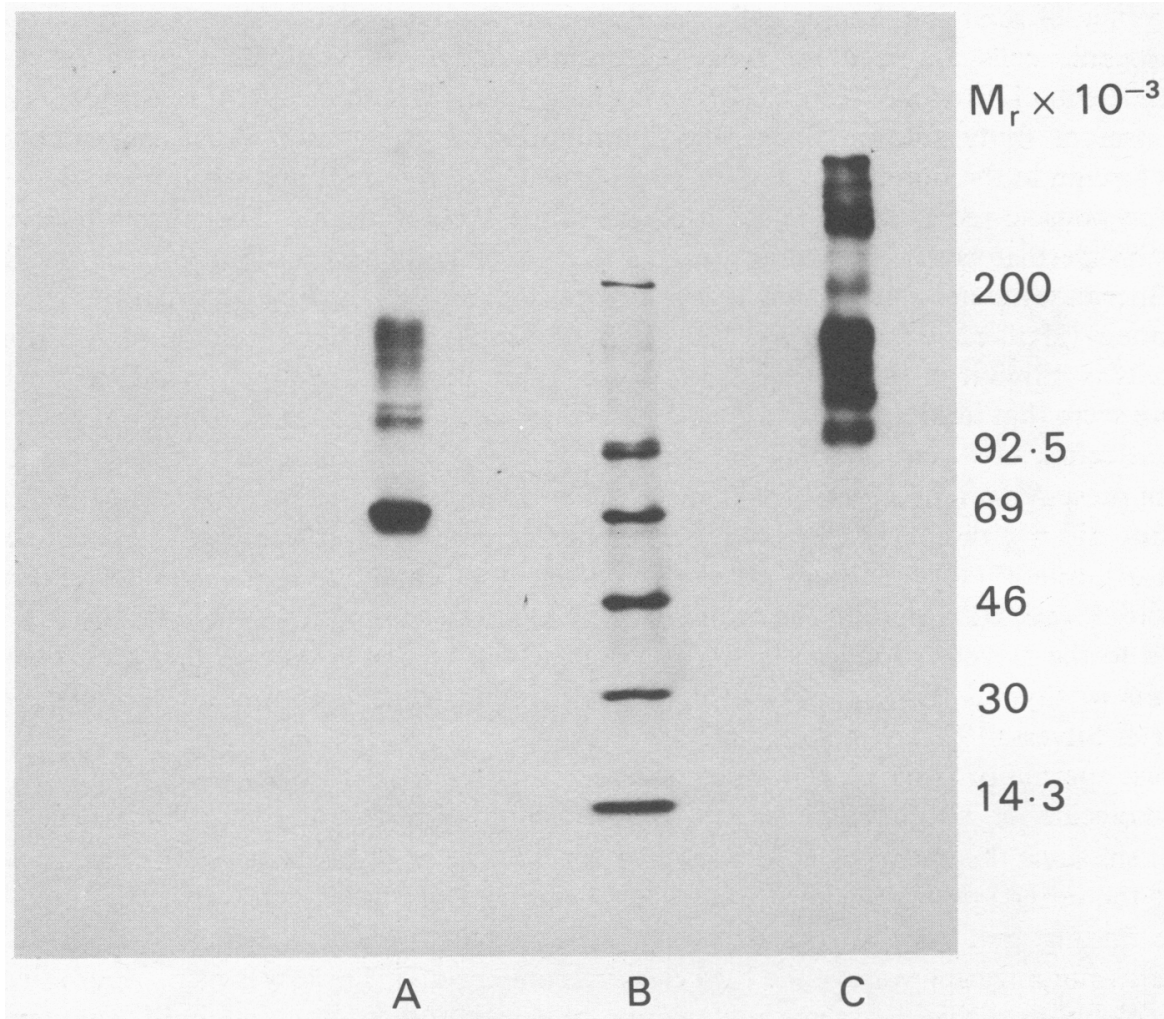

Text-fig. 5.SDS-PAGE analysis of sperm membrane proteins after transfer to cellulose nitrate. Reduced (lane A) and non-reduced (lane C) samples were electrophoresed on the same gel. ${ }^{14} \mathrm{C}$ methylated protein standards (lane B) were myosin $\left(M_{r} 200000\right)$, phosphorylase b $\left(M_{r} 92500\right)$, bovine serum albumin $\left(M_{r} 69000\right)$, ovalbumin $\left(M_{r} 46000\right)$, carbonic anhydrase $\left(M_{r} 300000\right)$ and ribonuclease $\mathrm{A}\left(\mathrm{M}_{\mathrm{r}} 14300\right)$.

Sperm acrosome staining was not seen when the other antisperm monoclonal antibodies were substituted for MS-1 or when the conjugated antiserum was used alone. An isometric plot of relative light scatter of individual cells (representing cell size) and fluorescent intensity for an unfractionated sample of vas deferens and epididymal spermatozoa analysed with a flow cytometer is presented in Text-fig. 4. The fluorescence pattern of MS-1 on spermatozoa is bimodal and an unstained mixed population of spermatozoa and contaminating cells is also detected. It was possible to sort spermatozoa into fluorescence-positive and fluorescence-negative populations.

The molecular weight of the antigen recognized by antibody MS-1 was investigated by SDSPAGE analysis of sperm membrane proteins and by their electrophoretic transfer to nitrocellulose and development with monoclonal antibodies and ${ }^{125}$ I-labelled rabbit antimouse immunoglobulin. MS-1 bound predominantly to a protein with an apparent molecular weight of 69000 after pretreatment of NP40-solubilized proteins with the sulphydryl reagent 2-mercaptoethanol (reducing conditions). Under non-reducing conditions the antibody reacted with several protein species with apparent molecular weights greater than 98000 (Text-fig. 5).

\section{Discussion}

The percentage of hybrid cell lines generating antisperm antibodies was low $(2 \%)$, in close agreement with values reported by Feuchter et al. (1981) following isogeneic immunization of B6 male mice with spermatozoa. 
By virtue of their immunologically privileged environment it has been suggested that when spermatogenic cells are used for syngeneic immunization, they should elicit a tissue-specific response (Bechtol, Brown \& Kennet, 1979; Bechtol, Jonak \& Kennet, 1980; Feuchter et al., 1981). In the present study autosomal syngeneic immunizations were used because spermatozoa are equally foreign to the immune system of an isogeneic virgin female and in addition may elicit an allergic response directed against gene products of the $\mathrm{Y}$ chromosome. The concentration of $\mathrm{H}-\mathrm{Y}$ antigen on spermatozoa is considerably higher than on male spleen cells (Katsh, Talmage \& Katsh, 1964). Spermatozoa are amongst the few cell types susceptible to killing by anti-H-Y antisera and complement (Hall \& Wachtel, 1980); that spermatozoa have a higher density of H-Y antigen than other cells is implicit in this observation (Winn, 1962; Linscott, 1970; Johnson, 1970). It would therefore seem that immunization and assay with syngeneic spermatozoa is an appropriate system for the selection of $\mathrm{Y}$ chromosome-limited and sperm-specific monoclonal antibodies. It is clear from the present data, however, that none of the antibodies obtained possessed anti-H-Y activity since they did not discriminate between male and female cells. It has been reported that $\mathrm{H}-\mathrm{Y}$ antigen is limited in distribution to the region of the acrosomal cap in mouse spermatozoa (Koo, Stackpole, Boyse, Hämmerling \& Lardis, 1973). The antigen recognized by antibody MS-1 is also confined to the acrosomal region of the sperm head but was not detected on adult male spleen, epidermis or thymus tissues which are $\mathrm{H}-\mathrm{Y}$ positive in transplantation and serological assays (Gasser \& Silvers, 1972; Wachtel, 1977).

Mouse spermatozoa have been shown to bind immunoglobulins specifically via the Fc portion of the molecule. It is unlikely, however, that the binding of the MS-1 antibody occurs by this mechanism since the sperm receptors are Fc $\gamma$-specific (Sethi \& Brandis, 1980), and, in addition, none of the other IgM monoclonal antibodies examined produced acrosomal staining.

The finding that all the sperm-reactive monoclonal antibodies produced after autosomal syngeneic immunization were of the IgM class was unexpected. There was no obvious selection for immunoglobulins of this class since polyvalent rabbit anti-mouse immunoglobulin was employed as detecting reagent in the serological screening procedures. Class restriction of the humoral response may be influenced by the nature of the immunogen or result from a genetic predisposition for the selective production of immunoglobulin of defined isotype. Evidence supporting the latter possibility has been obtained in studies of B6 mice which produce predominantly IgM antibodies after hyper-immunization with sheep red blood cells (Silver \& Winn, 1973; Haber \& Winn, 1981). The observation that of the 14 B6 monoclonal IgM immunoglobulins only MS-1 bound protein A is consistent with a previous report (MacKenzie, Gutman \& Warner, 1978) that murine protein Areactive $\mathrm{IgM}$ proteins are uncommon. It would be inappropriate, therefore, to use this reagent in preliminary screening assays for monoclonal antibodies under conditions favouring selection for $\operatorname{IgM}$.

The identification of a specific antigen on spermatozoa is confounded by the presence of autoantibodies in normal and conventional immune sera and by the observation that only a small fraction of the cells are reactive in serological assays (Fellous, Gachelin, Buc-Caron, Dubois \& Jacob, 1974). The application of homogeneous antibodies produced in vitro by hybridoma technology after appropriate immunization and screening will largely circumvent the first of these problems. In addition it is unnecessary (and futile) to perform adsorption studies (as shown by $\mathrm{H}-\mathrm{Y}$ serology, Beutler, Nagai, Ohno, Klein \& Shapiro, 1978; Koo, 1981) which are often cumbersome and generally result in loss of titre (Yelton \& Scharff, 1981). The ability to examine cross-reactions, such as those observed in the present study, is one of the most powerful applications of monoclonal antibodies (Yelton \& Scharff, 1981).

Biochemical analysis showed that the MS-1 antibody bound predominantly to a sperm membrane protein of apparent molecular weight 69000 (lane A, Text-fig. 5) but binding also occurred to other higher molecular weight proteins. Further studies are required to determine whether this indicates that identical epitopes, possibly carbohydrate in nature, are present on these higher molecular weight proteins or that the higher molecular weight components represent 
aggregates or polymers of the $69000 \mathrm{M}_{\mathrm{r}}$ protein. The alternative explanation that the MS-1 antibody is polyclonal seems unlikely since the hybridoma has been subcloned twice and grown continuously in vitro for several months.

Suspensions of mouse spermatozoa have been shown to behave as heterogeneous populations in cytotoxicity assays (Yanagisawa, Bennett, Boyse, Dunn \& Dimeo, 1974) although no plausible explanation has been offered to account for such results (Fellous et al., 1974). Similarly, MS-1 antigen was detectable on only $42 \%$ of spermatozoa in immunofluorescence studies. This heterogeneity is probably due to the mixed populations of mouse spermatozoa, derived from the vasa deferentia and the epididymides, commonly employed in serological investigations. Biochemical data indicate that the MS-1 antigen is a disulphide-bonded polymeric protein of high molecular weight. A high content of cysteine is present in spermatozoa from which disulphide cross links are formed during their passage through the epididymis (Calvin, 1975). It is possible, therefore, that the immunofluorescent-negative spermatozoa observed in the present study represent less mature cells.

The topographically restricted distribution of the MS-1 antigen is consistent with the mosaic distribution of sperm-surface components demonstrated by a variety of cell surface labelling procedures (Koehler, 1978) and more recently with monoclonal antibodies (Myles, Primakoff \& Bellvé, 1981 ; Feuchter et al., 1981). It should now be possible to examine the relationship between such molecules and specific functions of the sperm surface, for example the involvement of the MS1 protein in the acrosome reaction and its influence on sperm function during fertilization.

Postmeiotic expression of sperm antigens has been extensively sought with few convincing results (Johnson \& Howe, 1975) and it remains to be shown that continued haploid gene activity actually occurs (Festenstein et al., 1979). The demonstration here that it is possible to sort sperm populations in a flow cytometer after suitable immunofluorescent staining and that cells can be recovered in a viable state (Arndt-Jovin \& Jovin, 1977; Green et al., 1980) makes it feasible to test this hypothesis directly using artificial insemination when suitable probes are available.

We thank Dr V. van Heyningen for helpful advice; Dr C. M. Steel for critically reading the manuscript; Professor Sir Michael Woodruff, Dr M. Hooper and Dr R. A. J. McIlhinney for cultured cell lines; Dr D. K. Green for the FACS analysis; Mr N. Davidson and Mr D. Stuart for photographic illustrations; Mrs I. Cunnison for secretarial assistance and the staff of the Animal House, Western General Hospital for supplying the animals.

\section{References}

Arndt-Jovin, D.J. \& Jovin, T.M. (1977) Analysis and sorting of living cells according to deoxyribonucleic acid content. J. Histochem. Cytochem. 25, 585589 .

Bechtol, K.B., Brown, S.C. \& Kennet, R.H. (1979) Recognition of differentiation antigens of spermatogenesis in the mouse by using antibodies from spleen cell-myeloma hybrids after syngeneic immunization. Proc. natn. Acad. Sci. U.S.A. 76, 363-367.

Bechtol, K.B., Jonak, Z.L. \& Kennet, R.H. (1980) Germcell-related and nervous-system-related differentiation and tumor antigens. In Monoclonal Antibodies Hybridomas: A New Dimension in Biological Analyses, ch. 11, pp. 171-184. Eds R. H. Kennet, T. J. McKearn \& K. B. Bechtol. Plenum Press, New York.

Bedford, J.M., Cooper, G.W. \& Calvin, H.I. (1972) Postmeiotic changes in the nucleus and membranes of mammalian spermatozoa. In The Genetics of the Spermatozoon, pp. 69-89. Eds R. A. Beatty \& S. Gluecksohn-Waelsch. Departments of Genetics,
University of Edinburgh and Albert Einstein College of Medicine, Edinburgh and New York.

Bennett, D. \& Boyse, E.A. (1973) Sex ratio in progeny of mice, inseminated with sperm treated with $\mathrm{H}-\mathrm{Y}$ antiserum. Nature, Lond. 246, 308-309.

Beutler, B., Nagai, Y., Ohno, S., Klein, G. \& Shapiro, I.M. (1978) The HLA-dependent expression of testis organizing $\mathrm{H}-\mathrm{Y}$ antigen on human male cells. Cell 13, 509-513.

Burnette, W.N. (1981) "Western blotting": electrophoretic transfer of proteins from sodium dodecyl sulfate-polyacrylamide gels to unmodified and radiographic detection with antibody and radioiodinated protein A. Analyt. Biochem. 112, 195-203.

Calvin, H.I. (1975) Keratinoid proteins in the heads and tails of mammalian spermatozoa. In The Biology of the Male Gamete, pp. 257-273. Eds J. G. Duckett \& P. A. Racey. Academic Press, London.

Cohen, S. \& Milstein, C. (1967) Structure and biological properties of immunoglobulins. Adv. Immunol. 7, 189. 
Erickson, R.P (1972) Alternative modes of detection of $\mathrm{H}-2$ antigens on mouse spermatozoa. In The Genetics of the Spermatozoon, pp. 191-202. Eds R. A. Beatty \& S. Gluecksohn-Waelsch. Departments of Genetics, University of Edinburgh and Albert Einstein College of Medicine, Edinburgh and New York.

Fellous, M. \& Dausset, J. (1970) Probable haploid expression of HL-A antigens on human spermatozoa. Nature, Lond. 225, 191-193.

Fellous, M., Gachelin, G., Buc-Caron, M.-H., Dubois, P. \& Jacob, F. (1974) Similar location of an early embryonic antigen on mouse and human spermatozoa. Devl Biol. 41, 331-337.

Festenstein, H., Halim, K. \& Arnaiz-Villena, A. (1979) HLA antigens on human spermatozoa. In Spermatozoa, Antibodies and Infertility, ch. 2, pp. 11-16. Eds J. Cohen \& W. F. Hendry. Blackwell Scientific Publications, Oxford.

Feuchter, F.A., Vernon, R.B. \& Eddy, E.M. (1981) Analysis of the sperm surface with monoclonal antibodies: topographically restricted antigens appearing in the epididymis. Biol. Reprod. 24, 1099-1110.

Gasser, D.L. \& Silvers, W.K. (1972) Genetics and immunology of sex-linked antigens. Adv. Immunol. 15, 215-247.

Goldberg, E.H., Aoki, T., Boyse, E.A. \& Bennett, D. (1970) Detection of $\mathrm{H}-2$ antigens on mouse spermatozoa by the cytotoxicity test. Nature, Lond. 228, 570572.

Goldberg, E.H., Boyse, E.A., Bennett, D., Scheid, M. \& Carswell, E.A. (1971) Serological demonstration of H-Y (male) antigen on mouse sperm. Nature, Lond. 232, 478-480.

Green, D.K., Molloy, P. \& Steel, M. (1980) The recovery of living cells by flow sorting machine. Flow Cytometry 4, 103-106.

Haber, J. \& Winn, H.J. (1981) Genetic control of the expression of immunoglobulin isotypes in the responses of mice to sheep red blood cells. Eur. $J$. Immunol. 11, 671-678.

Hall, J.L. \& Wachtel, S.S. (1980) Primary sex determination : genetics and biochemistry. Molec. cell. Biochem. 33, 49-66.

Jensenius, J.C. \& Williams, A.F. (1974) The binding of anti-immunoglobulin antibodies to rat thymocytes and thoracic duct lymphocytes. Eur. J. Immunol. 4, 91-97.

Johnson, M.H. (1970) Selective damage to spermatogenic cells of high antigenicity during auto-allergic aspermatogenesis. J. Path. 102, 131-138.

Johnson, M.H. \& Howe, C.W.S. (1975) The immunobiology of spermatozoa. In The Biology of the Male Gamete, pp. 205-214. Eds J. G. Duckett \& P. A. Racey. Academic Press, London.

Katsh, G.F., Talmage, D.W. \& Katsh, S. (1964) Acceptance or rejection of male skin by isologous female mice: effect of injection of sperm. Science, $N . Y$. 143, 41-42.

Kennet, R.H., Denis, K.A., Tung, A.S. \& Klinman, N.R. (1978) Hybrid plasmacytoma production: fusions with adult spleen cells, monoclonal spleen fragments, neonatal spleen cells and human spleen cells. Curr. Top. Microbiol. Immunol. 81, 77-91.

Koehler, J.K. (1978) The mammalian sperm surface: studies with specific labeling techniques. Int. Rev. Cytol. 54, 73-108.
Köhler, G. \& Milstein, C. (1975) Continuous cultures of fused cells secreting antibody of predefined specificity. Nature, Lond. 256, 495-497.

Koo, G.C. (1981) Serology of H-Y antigen. Hum. Genet. $58,18-20$.

Koo, G.C., Stackpole, C.W., Boyse, E.A., Hämmerling, U. \& Lardis, M.P. (1973) Topographical location of $\mathrm{H}-\mathrm{Y}$ antigen on mouse spermatozoa by immunoelectronmicroscopy. Proc. natn. Acad. Sci. U.S.A. 70, 1502-1505.

Laemmli, U.K. (1970) Cleavage of structural proteins during the assembly of the head of bacteriophage T4. Nature, Lond. 227, 680-685.

Linscott, W.D. (1970) Effect of cell surface antigen density on immunological enhancement. Nature, Lond. 228, 824-827.

MacKenzie, M.R., Gutman, G.A. \& Warner, N.L. (1978) The binding of murine IgM to staphylococcal $A$ protein. Scand. J. Immunol. 7, 367-370.

Mason, D.W. \& Williams, A.F. (1980) The kinetics of antibody binding to membrane antigens in solution and at the cell surface. Biochem. $J .187,1-20$.

Metz, C.B. (1972) Effects of antibodies on gametes and fertilization. Biol. Reprod. 6, 358-383.

Metzger, H. (1970) Structure and function of $\gamma \mathrm{M}$ macroglobulins. Adv. Immunol. 12, 57-116.

Millette, C.F. \& Bellvé, A.R. (1977) Temporal expression of membrane antigens during mouse spermatogenesis. J. Cell Biol. 74, 86-97.

Myles, D.G., Primakofi, P. \& Bellvé, A.R. (1981) Surface domains of the guinea pig sperm defined with monoclonal antibodies. Cell 23, 433-439.

Sethi, K. \& Brandis, H. (1980) IgG Fc-binding receptors on spermatozoa. Eur. J. Immunol. 10, 964-965.

Silver, D.M. \& Winn, H.J. (1973) Variations in the responses of C57BL and A mice to sheep red blood cells. II. Analysis of plaque-forming cells. Cell. Immunol. 7, 237-245.

Toullet, F. \& Voisin, G.A. (1974) Spermatotoxic, spermagglutinating and cytotoxic activities of guinea-pig autoantibodies to sperm autoantigen T. $J$. Reprod. Fert. 37, 299-313.

Vojtiskova, M. \& Pokorna, Z. (1972) Cellular antigens of mouse spermatozoa as possible markers of gene action. In The Genetics of the Spermatozoon, pp. 160 176. Eds R. A. Beatty \& S. Gluecksohn-Waelsch. Departments of Genetics, University of Edinburgh and Albert Einstein College of Medicine, Edinburgh and New York

Wachtel, S.S. (1977) H-Y antigen : genetics and serology. Immunological Rev. 33, 33-58.

Weber, K. \& Osborn, M. (1969) The reliability of molecular weight determinations by dodecyl sulfatepolyacrylamide gel electrophoresis. J. biol. Chem. 244, 4406-4412.

Williams, A.F. (1973) Assays for cellular antigens in the presence of detergents. Eur. J. Immunol. 3, 628-632.

Winn, H.J. (1962) The participation of complement in isoimmune reaction. Ann. N.Y. Acad. Sci. 101, 23-45.

Yanagisawa, K., Bennett, D., Boyse, E.A., Dunn, L.C. \& Dimeo, A. (1974) Serological detection and identification of sperm antigens specified by lethal t-alleles in the mouse. Immunogenetics 1, 57-67.

Yelton, D.E. \& Scharf, M.D. (1981) Monoclonal antibodies: a powerful tool in biology and medicine. Ann. Rev. Biochem. 50, 657-680. 